\title{
Design and Limited Trial of Financial Planning Web- Based Application Development for Indigenous Communities at Village Credit Institution in Badung Regency, Bali
}

\author{
I Made Wijana*, I Ketut Suwintana, Anak Agung \\ Putri Suardani \\ Accounting Department \\ Politeknik Negeri Bali \\ Badung, Indonesia \\ *imdwjn@gmail.com, tutswint@pnb.ac.id, \\ suardaniputri@yahoo.com
}

\author{
I Gusti Putu Fajar Pranadi Sudhana \\ Tourism Department \\ Politeknik Negeri Bali \\ Badung, Indonesia \\ fajar.pranadi@gmail.com
}

\begin{abstract}
This research aims to carry out the second stage of the research "Developing Financial Web-based application for Indigenous Village Communities at Village Credit Institution or Lembaga Perkreditan Desa (LPD) in Badung Regency, Bali”. This stage includes: design and coding as well as limited trial of the Financial Planning Web-based Application. Forty respondents from four of six districts in Badung Regency, The Province of Bali namely Abiansemal, Mengwi, Kuta Utara, and Kuta participated in this research. Their perception is gathered using a questionnaire that consist of four aspects namely Usability, Functionality, Satisfaction, and Innovativeness with 10 items. The validity of the application output is tested by six validators which are representatives of six LPD di Badung regency. The results of the research show (1) The design of the Financial Planning Web-based Application is related to design of database, input and output. The database consists of four tables while input and output are related to the output of tables as well as the interactive form and detail of financial planning products which are already available at LPDs in Badung Regency. Coding of the application was created using PHP programming language. In coding to display tables, nested looping facilities are used in the PHP programming language, (2) The results of limited trial show that six cluster test which consist of 22 items are valid. Finally, user's assessment on the feasibility of application shows all aspects namely Usability, Functionality, User Satisfaction, and Innovativeness get average scores above 2.50 and overall average scores of 3.27 out of 4.0.
\end{abstract}

Keywords-design, limited trial, application development, financial planning, village credit institution, LPD

\section{INTRODUCTION}

Having a good finance is one of the factors that can make someone happy and that can be achieved by doing financial planning early on. Many research concerning financial planning are carried out, such as examining behavioural factors, which lead households toward savings and financial planning [1]. An integrated model for financial planning has been developed which incorporates the time and the expected nature of financial events [2]. Research conducted by Liman and Hananto [3] aims to help Indonesian people to aware about total individual retirement fund by calculating their individual retirement fund using five variables namely expenses ratio, inflation rate, net interest rate, productive years, and retirement years. Murphy and Yetmar [4] found most respondents feel both that financial planning is important and that they are interested in developing a financial plan, very few feel that they have the necessary skills and knowledge to prepare their own plan. Research involved teachers of higher education in Warangal City, India found no significant difference in the perception of Technical and Non-Technical teachers towards the financial literacy and financial planning [5]. Huang [6] concluded that college graduate carried out financial plan such as making a budget which serves to direct wise spending, managing credits which deals with smart borrowing, saving for the future which prepares graduates for emergencies and small extra funds and lastly, it will talk about smart investing which can bring about large wealth to college graduates who start out with little money.

In Bali, people need funding for religious ceremonial costs, primary needs, education, and health costs beside retire expenses. To meet their needs in the future, they should prepare financial planning. Potential financial institutions that can provide financial planning services for indigenous peoples in Bali, especially in Badung Regency are Village Credit Institutions or Lembaga Perkreditan Desa (LPD) in their respective indigenous villages. Purbadharmaja et al., [7] stated, Village Credit Institution or Lembaga Perkreditan Desa (LPD) is a traditional micro finance institution in Bali. It's called 
traditional because they operate based on local government regulation which is roots from traditional village rules (namely awig-awig). According to Budiasni et al., [8] Village Credit Institutions (LPD) in Bali is unique where its operations thick with elements of local wisdom such as Tri Hita Karana, the concept which comes from the culture of the people in Bali. Village Credit Institutions is governed by the local laws passed by the governor of Bali, with the occurrence of Bali Provincial Regulation No. 4 year 2012 regarding the Second Amendment Bali Provincial Regulation No. 8 year 2002 regarding Credit Institutions village. The important role of the LPD is felt by the community, especially to support activities such as the odalan and the Hindu holidays. LPD has specific characteristic in management where it uses customary rules, norms, social sanction, and their rural leader involvement in the selection process and agreement maintenance [9]. The purpose of establishment of a Village Credit Institutions at every indigenous village, based on the elucidation of Regional regulation No. 2/1988 and No. 8 year 2002 regarding credit institutions village (LPD) and also on the page official page agencies Village Credit, is to support rural economic development through increased savings habits of rural communities and to provide credit to small-scale enterprises, to eliminate the form - a form of exploitation in relation to credit, to create equal opportunities for the business activities at the village level, and increase the level of monetization of the rural areas [10]. LPD is a financial institution that specifically and only in society Pakraman with operational limits even though he does not have legislation providing status as rural banks (BPR).

LPD as financial institutions of Bali indigenous communities have an important role in the functioning of financial intermediation. Since its establishment, the LPD showed a good performance. As financial institution in a traditional (adat) village, LPDs collect funds through savings programs such as deposits and savings from the community which will be distributed in the form of loans. Savings programs that are widely available in LPDs, especially in Badung Regency which aim at financial planning for indigenous peoples are "planned savings". There are two types of savings plans available in the LPD, namely, first with a fixed payment every month and second with a payment at the beginning of the program. The planned savings in the LPD Legian, in Kuta District are called SIMPEL (Simpanan Pelajar) planned for education costs and the TAPURA (Tabungan Upacara) planned for the cost of traditional ceremonies are the first type and TAHTA (Tabungan Hari Tua) planned for future costs pensions is the second type.

In general, savings programs in LPDs, especially "planned savings", have been managed on a computer-based, but the information is still not accessible to the public from the internet. Managing savings that can be accessed online is very important. Therefore, this research developed a web-based financial planning application at Village Credit Institutions in Badung Regency, Bali. Using this web-based application, indigenous people in Badung Regency who are customers more easily access information about financial planning products in the LPDs.

In developing an application, System Development Life Circle (SDLC) method can be applied which consist of six steps: (1) system engineering, (2) analysis, (3) design, (4) coding, (5) testing, and (6) maintenance. Step (1) and step (2) have been implemented in the previous research stages. This research focuses on carrying out step (3) design and (4) coding as well as the limited trial of the application [11]

Based on the background above, then issue of concerns in this paper are: (a) How do the design and coding of Financial Planning Web-based Application For Indigenous Village Communities at LPD in Badung Regency? (b) How do limited trial results of Financial Planning Web-based Application For Indigenous Village Communities at LPD in Badung Regency? The purpose of this research are: (a) To know the design and coding of Financial Planning Web-based Application For Indigenous Village Communities at LPD in Badung Regency. (b) To Know limited trial results of Financial Planning Webbased Application For Indigenous Village Communities at LPD in Badung Regency.

\section{RESEARCH MethodolOGY}

This is the second stages of the research to developed Financial Planning Web-Based Application for Indigenous Village Communities at LPD in Badung Regency, The Province of Bali, Indonesia. In the first stages, this research has conducted analysis and system engineering and followed by the second stages including design and coding as well as limited trial. Forty respondents from four of six districts in Badung Regency, the Province of Bali namely Abinsemal, Mengwi, Kuta Utara, and Kuta participated in this research. Their perception is gathered using a questionnaire that consist of four aspects namely Usability, Functionality, and Satisfaction, Innovativeness with 10 items. The validity of the application output is tested by six validators which are representatives of six LPD di Badung regency.

\section{RESULTS AND DISCUSSION}

\section{A. Results}

1) Design: The design of Financial Planning Web-based Application For Indigenous Village Communities at Financial Credit Institution (LPD) in Badung Regency consist of design of database, input, output and process. An high quality application relies upon the support of very much welldesigned system structure [12].

In this research, the MySQL database that support the application, contains some tables. The first table is lpdlpd which consist of five columns: nolpd, namalpd, kecamatan desaadat, and telepon as can be seen in Figure 1. 


\begin{tabular}{|llll} 
& $\#$ & Name & Type \\
$\square$ & 1 & nolpd & tinyint(3) \\
$\square$ & 2 & namalpd & $\operatorname{varchar}(30)$ \\
$\square$ & 3 & kecamatan & $\operatorname{varchar}(20)$ \\
$\square$ & 4 & desaadat & $\operatorname{varchar}(25)$ \\
$\square$ & 5 & telepon & $\operatorname{varchar}(12)$
\end{tabular}

Fig. 1. Structure of Table lpdlpd.

The second, the third, and the forth table can be seen in Figure 2 to Figure 4.

\begin{tabular}{|l|lll}
\hline & \# & Name & Type \\
$\square$ & 1 & nopk & tinyint(3) \\
$\square$ & 2 & nojenispk & tinyint(2) \\
$\square$ & 3 & namapk & $\operatorname{varchar}(25)$ \\
$\square$ & 4 & nolpd & tinyint(3) \\
$\square$ & 5 & skbunga & $\operatorname{decimal}(2,2)$
\end{tabular}

Fig. 2. Structure of table produkpklpd.

\begin{tabular}{|llll} 
& \# & Name & Type \\
$\square \quad 1$ & nojenispk & tinyint(2) \\
$\square$ & 2 & namajenispk & $\operatorname{varchar}(40)$
\end{tabular}

Fig. 3. Structure of table jenispk.

\begin{tabular}{|l|lll}
\hline \# & Name & Type \\
$\square$ & 1 & id & int(11) \\
$\square$ & 2 & username & $\operatorname{varchar}(32)$ \\
$\square$ & 3 & password & $\operatorname{varchar}(32)$ \\
$\square$ & 4 & nama & $\operatorname{varchar}(32)$ \\
$\square \quad 5$ & email & $\operatorname{varchar}(32)$ \\
$\square$ & 6 & nolpd & $\operatorname{tinyint}(3)$ \\
$\square$ & 7 & jenisuser & $\operatorname{varchar}(5)$
\end{tabular}

Fig. 4. Structure of table user.

The application was designed to be able to display several important outputs of financial planning products in six LPDs in Badung Regency, Bali Province, namely LPD Legian, Sibang Kaja LPD, Kerobokan LPD, Kuta LPD, Lukluk LPD and Sempidi LPD. The outputs are categorized into two namely: 1) tables and 2) interactive forms and details. There are two type of financial planning products which are available in LPD: 1) Type I is fixed deposit every month (A) and withdrawal once at the end of the program (Sn) and 2) Type II is deposit once at the beginning $(\mathrm{P})$ and withdrawal once at the end of the program (Pn).

Firstly, an example of $\mathrm{Sn}$ table is financial planning products of Legian LPD "SIMPEL" or "Simpanan Pelajar" with 3 columns and 12 rows (n) can be seen in Figure 4 while an example of Pn table is financial planning product of Sibang Kaja LPD "TSA" or "Tabungan Sayang Anak" with 4 columns and 10 rows $(\mathrm{n})$ which is described in Figure 5.
Tabel Nilai Akhir(Sn)Program Tabungan: SIMPEL(Simpanan Pelajar) LPD LEGLAN

Setoran/Bulan A

Dengan Suku Bunga $/$ Bulan $=0.414 \%$ atau $4.968 \%$ per Tahu

\begin{tabular}{|c|c|c|c|}
\hline Jangka Waktu & $A=$ & $A=$ & $A=$ \\
\hline (Tahun) & 100,000 & 200,000 & 300,000 \\
\hline 1 & $1,227,705$ & $2,455,409$ & $3,683,114$ \\
\hline 2 & $2,517,810$ & \begin{tabular}{|l|l|}
$5,035,619$ \\
\end{tabular} & $7,553,429$ \\
\hline 3 & $3,873,487$ & 7,746,974 & $11,620,461$ \\
\hline 4 & $5,298,069$ & \begin{tabular}{|l|l|l|}
$10,596,138$ \\
\end{tabular} & $15,894,208$ \\
\hline 5 & $6,795,059$ & 13,590,117 & $20,385,176$ \\
\hline 6 & $8,368,135$ & $|16,736,271|$ & $25,104,406$ \\
\hline 7 & $10,021,167$ & $20,042,334$ & $30,063,501$ \\
\hline 8 & $11,758,217$ [ & $23,516,434$ — & $35,274,652$ \\
\hline 9 & $13,583,556$ & $27,167,113$ & $40,750,669$ \\
\hline 10 & $15,501,672$ & $31,003,344$ & $46,505,016$ \\
\hline 11 & $17,517,280$ & $35,034,559$ & $52,551,839$ \\
\hline 12 & $19,635,335$ & $39,270,669$ & $58,906,004$ \\
\hline
\end{tabular}

Fig. 5. Table of Sn of financial planning product of Legian LPD "SIMPLE".

\begin{tabular}{|c|c|c|c|c|c|}
\hline Jangka Waktu & $\mathrm{P}=$ & $\mathbf{P}=$ & $\mathbf{P}=$ & $\mathbf{P}=$ & $\mathrm{P}=$ \\
\hline (Tahun) & $1,000,000$ & $2,000,000$ & $3,000,000$ & $4,000,000$ & $5,000,000$ \\
\hline 1 & \begin{tabular}{|l|}
$1,100,000$ \\
\end{tabular} & $2,199,000$ & $3,299,000$ & \begin{tabular}{|l|}
$4,399,000$ \\
\end{tabular} & $5,498,000$ \\
\hline 2 & $1,209,000$ & $2,418,000$ & $3,628,000$ & $4,837,000$ & $6,046,000$ \\
\hline 3 & $1,330,000$ & $2,660,000$ & $3,989,000$ & $5,319,000$ & $6,649,000$ \\
\hline 4 & $1,462,000$ & $2,925,000$ & $4,387,000$ & $5,849,000$ & $7,311,000$ \\
\hline 5 & $1,608,000$ & $3,216,000$ & $4,824,000$ & $6,432,000$ & $8,040,000$ \\
\hline 6 & $1,768,000$ & $3,537,000$ & $5,305,000$ & $7,073,000$ & $8,841,000$ \\
\hline 7 & $1,944,000$ & $3,889,000$ & $5,833,000$ & $7,778,000$ & $9,722,000$ \\
\hline 8 & $2,138,000$ & $4,277,000$ & $6,415,000$ & $8,553,000$ & $10,691,000$ \\
\hline 9 & $2,351,000$ & $4,703,000$ & $7,054,000$ & $9,405,000$ & $11,757,000$ \\
\hline 10 & $2,586,000$ & $5,171,000$ & $7,757,000$ & $10,343,000$ & $12,928,000$ \\
\hline
\end{tabular}

Fig. 6. Table of Pn of financial planning product of Sibang Kaja LPD "TSA".

Similar Sn table to the Legian LPD "SIMPEL" can be created by the application namely Legian LPD "TAPURA", Sibang Kaja LPD "SIMADEJA", Sibang Kaja LPD "TAMASDE", Kerobokan LPD "SUPUTRA", Kuta LPD "SIMADE", Lukluk LPD "TAPA" and Sempidi LPD "SIBERMAS". The application also was designed to be able to create similar Pn table to the Sibang Kaja "TSA" namely Legian LPD "TAHTA" and Lukluk LPD "TAPA Plus"

The tables in Figures 5 and Figure 6 are related to the input form in the Figure 7 and Figure 8 respectively.

Tabel SIMPEL (Simpanan Pelajar) LPD Legian

Tabel Perencanaan Keuangan Ini Dengan Menyetor Tiap Bulan A Selama n Tahun Lalu Bisa Menarik Sn di Akhir Program
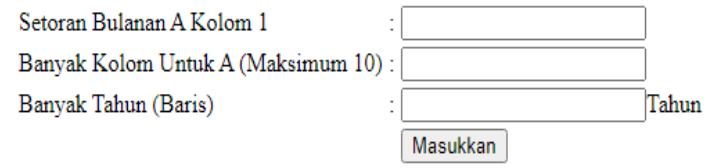

Fig. 7. Input form of Legian LPD "SIMPLE" table. 
Tabel TSA(Tabungan Sayang Anak) LPD Sibang Kaja

Tabel Perencanaan Keuangan, Dengan Menyetor Sekali Di Awal P, Mengendap Selama n Tahun

Bisa Menarik Pn di Akhir Program

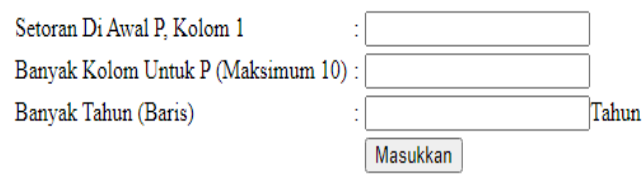

Fig. 8. Input form of Sibang Kaja LPD "TSA" table.

Secondly, an example of Sn interactive form and detail is financial planning product of Kuta LPD "SIMADE" or "Simpanan Masa Depan" can be seen in Figure 9 and Figure 10 while an example of Pn interactive form and detail is financial planning product of Legian LPD "TAHTA" or "Tabungan Hari Tua" as described in Figure 11 dan Figure 12.

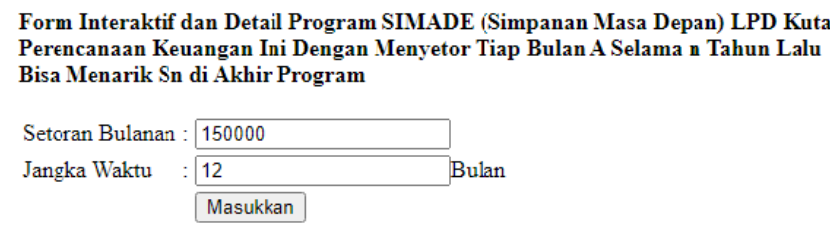

Fig. 9. Input form of Kuta LPD "SIMADE” table.

Nilai Setoran $/$ Bulan $=150,000$

Nilai Suku Bunga/Bulan $=0.46 \%$

Jangka Waktu $\mathrm{n}=12$ bulan

Nilai Total di Akhir $\mathrm{Sn}=1,846,246$

Tabel Detail Mencari Nilai Akhir (Sn)

Program Program SIMADE (Simpanan Masa Depan) LPD Kuta

\begin{tabular}{|c|r|r|r|}
\hline NO & \multicolumn{1}{|c|}{ SETOR } & \multicolumn{1}{c|}{ BUNGA } & \multicolumn{1}{c|}{ SALDO } \\
\hline \hline 1 & 150,000 & 0 & 150,000 \\
\hline \hline 2 & 150,000 & 690 & 300,690 \\
\hline \hline 3 & 150,000 & 1,383 & 452,073 \\
\hline \hline 4 & 150,000 & 2,080 & 604,153 \\
\hline \hline 5 & 150,000 & 2,779 & 756,932 \\
\hline \hline 6 & 150,000 & 3,482 & 910,414 \\
\hline \hline 7 & 150,000 & 4,188 & $1,064,602$ \\
\hline \hline 8 & 150,000 & 4,897 & $1,219,499$ \\
\hline \hline 9 & 150,000 & 5,610 & $1,375,108$ \\
\hline \hline 10 & 150,000 & 6,325 & $1,531,434$ \\
\hline \hline 11 & 150,000 & 7,045 & $1,688,479$ \\
\hline \hline 12 & 150,000 & 7,767 & $1,846,246$ \\
\hline
\end{tabular}

Fig. 10. Detail of Kuta LPD “SIMADE”.

Form Interaktif dan Detail Program TAHTA (Tabungan Hari Tua) LPD Legian

Tabel Perencanaan Keuangan, Dengan Menyetor Sekali Di Awal P, Mengendap Selama n Tahun Bisa Menarik Pn di Akhir Program

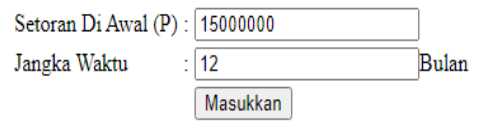

Fig. 11. Input form of Legian LPD "TAHTA" table.
Nilai Setoran di Awal $=15,000,000$

Nilai Suku Bunga/Bulan $=0.414 \%$

Jangka Waktu $\mathrm{n}=12$ bulan

Nilai Total di Akhir Pn $=15,762,405$

Tabel Detail Mencari Nilai Pn

Program TAHTA (Tabungan Hari Tua) LPD Legian

\begin{tabular}{|c||r||r|r|}
\hline NO & SETOR & BUNGA & \multicolumn{1}{c|}{ SALDO } \\
\hline \hline 1 & $15,000,000$ & 62,100 & $15,062,100$ \\
\hline 2 & 0 & 62,357 & $15,124,457$ \\
\hline 3 & 0 & 62,615 & $15,187,072$ \\
\hline 4 & 0 & 62,874 & $15,249,947$ \\
\hline 5 & 0 & 63,135 & $15,313,082$ \\
\hline \hline 6 & 0 & 63,396 & $15,376,478$ \\
\hline 7 & 0 & 63,659 & $15,440,136$ \\
\hline 8 & 0 & 63,922 & $15,504,059$ \\
\hline \hline 9 & 0 & 64,187 & $15,568,245$ \\
\hline 10 & 0 & 64,453 & $15,632,698$ \\
\hline \hline 11 & 0 & 64,719 & $15,697,417$ \\
\hline 12 & 0 & 64,987 & $15,762,405$ \\
\hline
\end{tabular}

Fig. 12. Detail of Legian LPD "TAHTA".

2) Coding: This stage is to create code of the program. Coding is a process of translating the design results into a form can be read by a computer. Application developed in this research is web-based application, where the program code is created using a programming language PHP.

3) Trial results of the application: Trial of the application uses black box testing method involving six validators. The scope of the test and the results can be seen in Figure 13 and Figure 14.

\begin{tabular}{|l|l|c|} 
No & \multicolumn{2}{|c|}{ Test Cluster } \\
\hline I & LPD Legian Financial Planning Products & Results \\
\hline \multirow{5}{*}{} & 1. Table of SIMPEL & Valid \\
\cline { 2 - 3 } & 2. Interactive Form and Detail of SIMPEL & Valid \\
\cline { 2 - 3 } & 3. Table of TAPURA & Valid \\
\cline { 2 - 3 } & 4. Interactive Form and Detail of TAPURA & Valid \\
\cline { 2 - 3 } & 5. Table of TAHTA & Valid \\
\cline { 2 - 3 } & 6. Interactive Form and Detail of TAHTA & Valid \\
\hline \multirow{5}{*}{ LPD Sibang Kaja Financial Planning Products } & Results \\
\cline { 2 - 3 } & 1. Table of SIMADEJA & Valid \\
\cline { 2 - 3 } & 2. Interactive Form and Detail of SIMADEJA & Valid \\
\cline { 2 - 3 } & 3. Table of TAMASDE & Valid \\
\cline { 2 - 3 } & 4. Interactive Form and Detail of TAMASDE & Valid \\
\cline { 2 - 3 } & 5. Table of TSA & Valid \\
\cline { 2 - 3 } & 6. Interactive Form and Detail of TSA & Valid \\
\hline
\end{tabular}

Fig. 13. Trial results of the application (Legian LPD and Sibang Kaja LPD). 


\begin{tabular}{|l|l|c|}
\hline No & \multicolumn{2}{|c|}{ Test Cluster } \\
\hline \multirow{4}{*}{ III } & LPD Lukluk Financial Planning Products & Results \\
\hline \multirow{4}{*}{} & 1. Table of TAPA & Valid \\
\cline { 2 - 3 } & 2. Interactive Form and Detail of TAPA & Valid \\
\cline { 2 - 3 } & 3. Table of TAPA PLUS & Valid \\
\cline { 2 - 3 } & 4. Interactive Form and Detail of TAPA PLUS & Valid \\
\hline \multirow{2}{*}{ LPD Kuta Financial Planning Products } & Results \\
\hline \multirow{2}{*}{} & 1. Table of SIMADE & Valid \\
\cline { 2 - 3 } & 2. Interactive Form and Detail of SIMADE & Valid \\
\hline \multirow{2}{*}{ VI } & LPD Kerobokan Financial Planning Products & Results \\
\cline { 2 - 3 } & 2. Table of SUPUTRA & Valid \\
\hline & LPD Sempidi Financial Planning Products & Valid \\
\cline { 2 - 3 } & 1. Table of SIBERMAS & Results \\
\cline { 2 - 3 } & 2. Interactive Form and Detail of SIBERMAS & Valid \\
\hline
\end{tabular}

Fig. 14. Trial results of the application (Lukluk LPD, Kuta LPD, Kerobokan LPD and Sempidi LPD).

Further investigation found feasibility of this application in four dimension namely Usability, Functionality, User Satisfaction, and Innovativeness involving forty respondents which are come from LPDs customers, LPDs employees, students, and other indigenous Communities. The Results can be seen in Figure 15.

\begin{tabular}{|c|c|c|}
\hline No & Aspect & \\
\hline \multirow[t]{6}{*}{$\mathbf{I}$} & Usability & Score \\
\hline & 1. This web-based application is easy to do & 3,50 \\
\hline & 2. Get financial planning information from this web-based application & 3,50 \\
\hline & $\begin{array}{l}\text { 3. Get knowledge about financial planning from this web-based } \\
\text { application }\end{array}$ & 3,60 \\
\hline & 4. Will use this web-based application for the future & 2,75 \\
\hline & Average Score & 3,34 \\
\hline \multirow[t]{4}{*}{ II } & Functionality & Score \\
\hline & 1. This application provides a complete financial planning simulation & 3,45 \\
\hline & $\begin{array}{l}\text { 2. This application provides a financial planning simulation that } \\
\text { matches the table in the program savings brochures from the LPD }\end{array}$ & 3,35 \\
\hline & Average Score & 3,40 \\
\hline
\end{tabular}

Fig. 15. Perception of the application feasibilty and aspect: usability and functionality.

\begin{tabular}{|c|c|c|}
\hline No & Aspect & \\
\hline \multirow[t]{4}{*}{ III } & User satisfaction & Score \\
\hline & $\begin{array}{l}\text { 1. With this application you can get savings program information } \\
\text { (financial planning) that exist in the LPD in Badung Regency }\end{array}$ & 3,45 \\
\hline & $\begin{array}{l}\text { 2. With this application you can get a simulation of financial planning, } \\
\text { especially savings programs that exist in the LPD in Badung } \\
\text { Regency }\end{array}$ & 3,45 \\
\hline & Average Score & 3,45 \\
\hline \multirow[t]{5}{*}{ IV } & Inovativeness & Score \\
\hline & $\begin{array}{l}\text { 1. This application provides examples of financial planning that are } \\
\text { not exist in the LPDs }\end{array}$ & 2,95 \\
\hline & $\begin{array}{l}\text { 2. This application provides a simulation of financial planning that } \\
\text { does not exist in the LPDs }\end{array}$ & 2,85 \\
\hline & Average Score & 2,90 \\
\hline & Overall Average Score & 3,27 \\
\hline
\end{tabular}

Fig. 16. Perception of the application feasibilty and aspect: user satisfaction and inovativeness.

\section{B. Discussion}

The development of the application has been in the design, coding, and limited trial stages. This web-based application is designed to be accessible from mobile phone and personal computer at the same time as developed by Hasan et al., [13]. The database design consist of main table namely lpdlpd, produkpklpd, jenisprodukpk, and user where Table of lpdlpd (see Figure 1) contains information about LPDs in Badung Regency, Table of produkpklpd (see Figure 2) contains information of financial planning products which are available at LPD in Badung Regency, Table of jenisprodukpk (see Figure 3) contains information type of financial planning products which are available at LPDs in Badung Regency, and Table of user (see Figure 4) contains information of financial planning web-based application user. The relation of all tables can be seen in Figure 17.

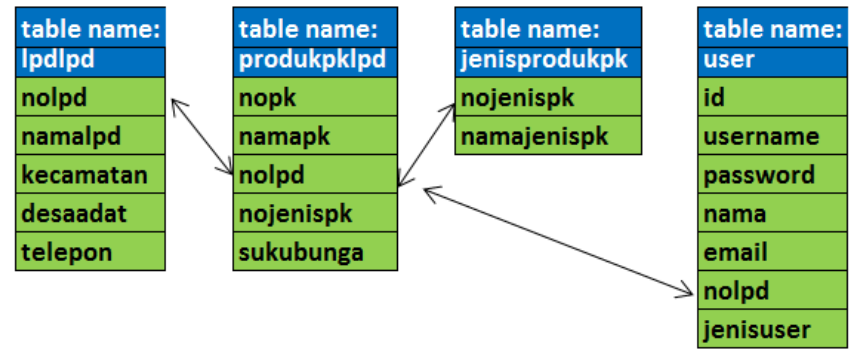

Fig. 17. Tables relation.

Based on the database with its tables, all output of the application such as tables as well as interactive form and of details of financial planning products of LPDs are developed. There are two type of Financial planning products which are available in LPDs. Type I is fixed deposit every month (A) and withdrawal once at the end of the program (Sn) such as the financial product of SIMPEL and TAPURA in Legian LPD or SIMADEJA and TAMASDE in Sibang Kaja LPD, SUPUTRA in Kerobokan LPD, SIMADE in Kuta LPD, TAPA ini Lukluk LPD and SIBERMAS in Sempidi LPD. The tables of these financial product need three variables namely: amount of deposit each month (A), number of columns in a table (an), the period of deposit in year (n), and the amount of interest rate/month (i). The first three variables can be inputted from an input form as descibed in Figure 6 and while the last variable is selected from variable sukubunga at Table produkpklpd. Basically the contents of the table $\mathrm{Sn}$ is applied a total ammount of annuity formula $\mathrm{Sn}=\mathrm{A}\left((1+\mathrm{i})^{\mathrm{n}}-1\right) / \mathrm{i}$ as shown in the main part of the PHP script. Nested looping techniques are applied to display the table as can bee seen in Figure 18 


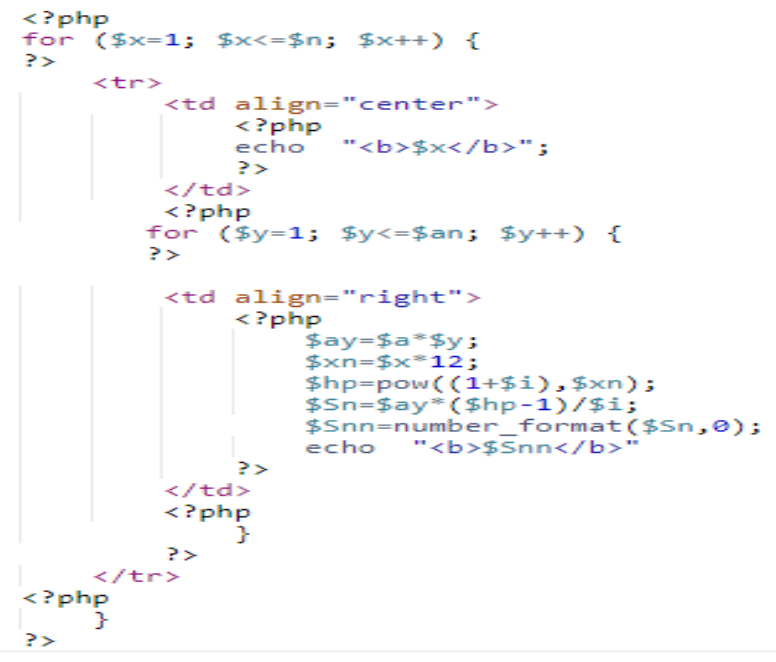

Fig. 18. The main PHP script of table Sn.

Similarly, financial planning products type II is deposit once at the beginning $(\mathrm{P})$ and withdrawal once at the end of the program $(\mathrm{Pn})$ such as TAHTA in LPD Legian, TSA in LPD Sibang Kaja, and TAPA Plus in LDP Lukluk. The tables of these financial product need theree variables namely: amount of deposit at the begining (P), number of columns in a table (an), the period of deposit in year (n), and the amount of interest rate/month (i). The first three variables can be inputted from an input form in Figure 7 while the last variable/interest rate (i) is selected from field sukubunga at Table produkpklpd. The interest rate (field sukubunga) can be updated by authorized users. The applications need to be updated frequently to maintain its reliability, efficiency and usability [14]. The contents of the table Pn is applied a compound interst formula $\mathrm{Pn}=\mathrm{P}(1+\mathrm{i}) \mathrm{n}$ as shown in the main part of the php script. Nested looping techniques are also applied to display the table as can be seen in Figure 19.

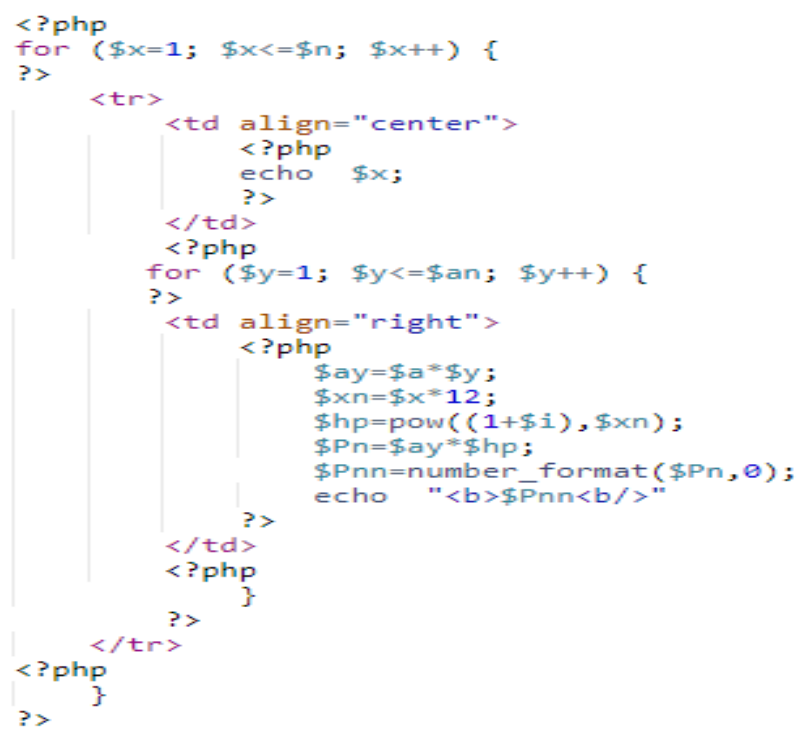

Fig. 19. The main PHP script of table Pn.
The application was also designed to be able to display interactive form and detail process of financial planning products type I Sn (See Figure 9) and financial planning products type II Pn (See Figure 10). Both need three variables namely: amount of deposit each month (A) or amount of deposit at the begining $(\mathrm{P})$, the period of deposit in year (n), and the amount of interest rate/month (i). They display $n$ rows and four columns (no, payment, interest, and balance). Nested looping is not applied and Figure 10 as well as Figure 21 show the main part of the PHP script.

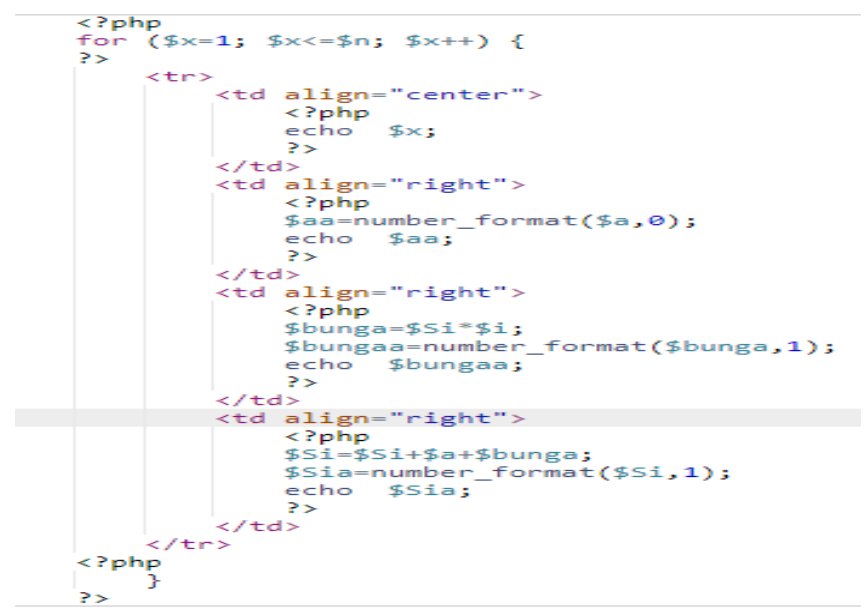

Fig. 20. The main PHP script of Sn detail.

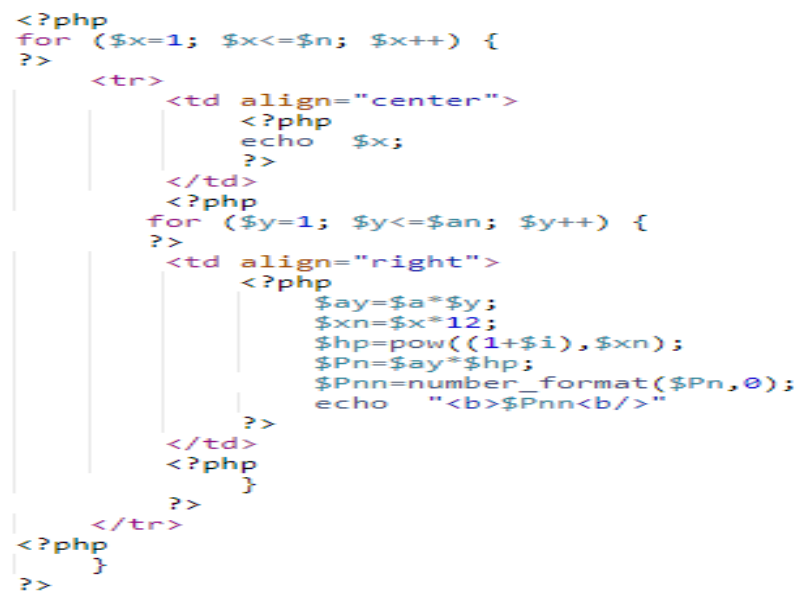

Fig. 21. The main PHP script of Pn detail.

All of the input and output of the application were tested by six representatives of LPDs in Badung Regency namely Legian LPD, Sibang Kaja LPD, Kerobokan LPD, Kuta LPD, Lukluk LPD, and Sempidi LPD. There are six cluster test that consist of 22 items to be filled in. The results in Figure 5 and Figure 6 show all items are valid. The application was also tried by 40 participants (users) to assess its feasibility. As can be seen in Figure 7 and Figure 8, the overall average score is 3.27 out of 4.0 (Good). The following Figure displays average score of each aspect. 


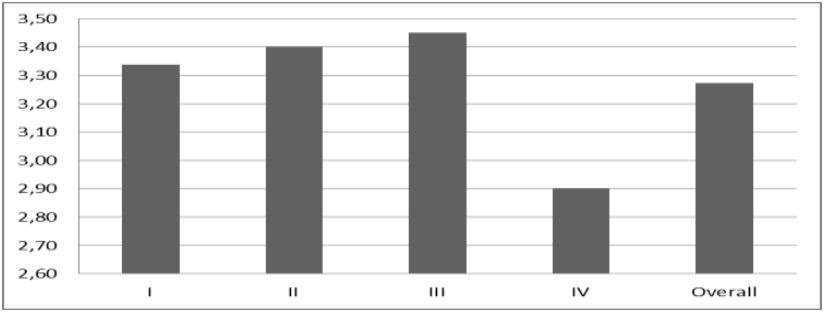

Fig. 22. Average score of every aspects and overall aspect.

As can be seen from Figure 22, all aspects (Usability, Functionality, User Satisfaction, and Innovativeness) are greater than 2.50. The greatest average score is User Satisfaction (3.60), in line with Mumpuni and Sukarno [15] and Deshpande et al., [16]. Aspect "Functionality" that was applied by Gavrivoka et al., [17], got the second greatest average score of 3.40 Figure 7 and Figure 8 show all items got score greater than 2.5. The maximum score is 3.60 and minimum score is 2.75 . It means the application are quite useful, quite functional, quite satisfying, and quite innovative.

\section{CONCLUSION}

Based on the results achieved previously, then the conclusion can be drawn as follows: (1) The design of the Financial Planning Web-based application is related to design of database, input and output. The database consists of four tables while input and output are related to the output of tables as well as the interactive form and detail of financial planning product which are already available at LPDs in Badung regency. Coding of the application was created using PHP programming language. In coding to display tables, nested looping facilities are used in the PHP programming language. (2) The results of limited trial show that six cluster test which consist of 22 items are valid. Finally, user's assessment on feasibility of the application shows all aspects namely Usability, Functionality, User Satisfaction, and Innovativeness got average scores above 2.50 and overall average score is 3.27 out of 4.0.

\section{ACKNOWLEDGMENT}

The author would like to thank: (1) DRPM KEMENRISTEK that has funded this research, (2) Director of Bali State Polytechnic who approved this research, and (3) LPD Legian, LPD Sibang Kaja, LPD Kerobokan, LPD Kuta, LPD Lukluk, LPD Sempidi and PLPD Badung Regency which has provided data to support this research.

\section{REFERENCES}

[1] D. Brounen, K.G. Kodijk, and R.A.J Pownall, "Household Financial Planning and Saving Behavior", Journal Of International Money and Financial, vol. 69, pp. 95-107, 2016.

[2] N. Cheifee and G.K. Rakes, "An Integrated Model for Financial Planning “, Financial Services Review, vol. 8, pp. 261-268, 1999.

[3] N. Liman and L.P. Hananto, "Financial Planning Determination Of Retirement Fund For Indonesian People: The Significant Of Expenses Ratio", Journal of Applied Finance and Accounting, vol. 1, no. 2, pp. 247-267, 2009.

[4] D.S. Murphy and S. Yetmar, "Personal financial planning attitudes: preliminary study of graduate students", Management Research Review, vol. 33 , no. 8 , pp. 811-817, 2010

[5] G. Surendar and V.V.S. Sarma, "Financial Literacy and Financial Planning among Teachers of Higher Education - A Comparative Study on Select Variables", Amity Journal Of Finanance, vol. 2, no. 1, pp. 3146, 2017.

[6] L.S Huang, "Personal Financial Planning for College Graduate" Technology and Investment, vol. 7, pp. 123-134, 2016.

[7] I.B.P Purbadharmaja, N. M. Trinawati, and N. P.W. Setyari,"Micro Finance Existence in Global Competition: Case Study of Balinese Traditional Microfinance Institution", IOSR Journal Of Humanities And Social Science, vol. 22, no. 9, pp. 9-14, 2017.

[8] N. Budiasni, S. Ayuni, and W. S. Sanjaya, "Sustainability Performance of Village Credit Institutions (LPD) in Buleleng Regency" International Journal of Social Science and Business, vol. 2, no.. 4, pp. 110-116, 2018

[9] I.P.Astawa, T.G.R. Sukawati, N.N Triyuni, and I.N. Abdi " Performance of Microfinance Institution In Harmony Cultural Perspective", Procedia Social and Behaviour Science, vol. 219, pp. 113-120, 2016

[10] J.I. Kosasih and D. Hendrawan, "Existence Of Entities "Village Credit Institutions/Lembaga Perkreditan Desa (LPD)" Local Community In Bali Viewed From Financial Control System In Indonesia”, IJABER vol. 14, no. $15,2016$.

[11] R.S Pressman, "Software Engineering: A Practitioner's Approach". 7Ed New York: McGraw-Hill International Editions, 2009.

[12] M.T. Mahmood, O.I. Ashour, O. Ucan and O. Bayat, "Design and Implementation of Web Based For Intermediate Online Shop with Laravel Framework" International Journal of Computer Science and Mobile Computing, vol. 8, no. 3, pp. 124-133, 2019.

[13] M.R. Hasan, M.I. Ibrahimy, and S.M.A. Motakabber, "Development of a Web Financial Appplication System" IOP Conf. Series: Materials Science and Engineering, vol. 53, no. 012080, pp 1-8, 2013.

[14] A. Abdul-Azis, A. Koronios, J. Gao and M.S. Sulong, "Towards Effective Development of Web-based Business Applications" Jurna Internet and e-Business Studi, 2012.

[15] M. Mumpuni and S. Sukarno, "Design and Implementation Money Management Web-based Application for Personal and Family Proposed for CV. X" The 5th Indonesia International Conference on Innovation, Entrepreneurship, and Small Business, 2013

[16] Y. Deshpande, S Murugesan, A Ginige, S Hansen, D Schwabe, M Gaedke, and, B White "Web Engineering," Journal of Web Engineering, vol. 1 , no. 1,2002

[17] V. Gafrikova, W Szczesny, and Z Odrzygóźdź, "Online Personal Finance Management Application" Information Systems in Management, vol. 4, no. 1, pp. 39-52, 2015. 